University of Nebraska - Lincoln

DigitalCommons@University of Nebraska - Lincoln

\title{
Incorporating field wind data to improve crop evapotranspiration parameterization in heterogeneous regions
}

\author{
Ray G. Anderson \\ USDA-ARS, ray.anderson@ars.usda.gov \\ Jorge F.S. Ferreira \\ USDA-ARS, Jorge.Ferreira@ars.usda.gov \\ Dennise L. Jenkins \\ USDA-ARS, dennise.jenkins@ars.usda.gov \\ Nildo da Silva Dias \\ USDA-ARS, nildo@ufersa.edu.br \\ Donald L. Suarez \\ USDA-ARS, donald.suarez@ars.usda.gov
}

Follow this and additional works at: https://digitalcommons.unl.edu/usdaarsfacpub

Anderson, Ray G.; Ferreira, Jorge F.S.; Jenkins, Dennise L.; da Silva Dias, Nildo; and Suarez, Donald L., "Incorporating field wind data to improve crop evapotranspiration parameterization in heterogeneous regions" (2017). Publications from USDA-ARS / UNL Faculty. 1831.

https://digitalcommons.unl.edu/usdaarsfacpub/1831

This Article is brought to you for free and open access by the U.S. Department of Agriculture: Agricultural Research Service, Lincoln, Nebraska at DigitalCommons@University of Nebraska - Lincoln. It has been accepted for inclusion in Publications from USDA-ARS / UNL Faculty by an authorized administrator of DigitalCommons@University of Nebraska - Lincoln. 


\title{
Incorporating field wind data to improve crop evapotranspiration parameterization in heterogeneous regions
}

\author{
Ray G. Anderson ${ }^{1} \cdot J^{\prime}$ Jorge F. S. Ferreira ${ }^{2} \cdot$ Dennise L. Jenkins $^{1} \cdot$ Nildo da Silva Dias $^{3} \cdot$ \\ Donald L. Suarez ${ }^{2}$
}

Received: 26 January 2017 / Accepted: 11 September 2017 / Published online: 16 September 2017

(c) US Government (outside the USA) 2017

\begin{abstract}
Accurate parameterization of reference evapotranspiration $\left(\mathrm{ET}_{0}\right)$ is necessary for optimizing irrigation scheduling and avoiding costs associated with over-irrigation (water expense, loss of water productivity, energy costs, and pollution) or with under-irrigation (crop stress and suboptimal yields or quality). $\mathrm{ET}_{0}$ is often estimated using the FAO-56 method with meteorological data gathered over a reference surface, usually short grass. However, the density of suitable $\mathrm{ET}_{0}$ stations is often low relative to the microclimatic variability of many arid and semi-arid regions, leading
\end{abstract}

Communicated by J. Chávez.

The U.S. Department of Agriculture (USDA) prohibits discrimination in all its programs and activities on the basis of race, color, national origin, age, and disability, and where applicable, sex, marital status, familial status, parental status, religion, sexual orientation, genetic information, political beliefs, reprisal, or because all or part of an individual's income is derived from any public assistance program. Not all prohibited bases apply to all programs. Persons with disabilities who require alternative means for communication of program information (Braille, large print, audiotape, etc.) should contact USDA's TARGET Center at (202) 720-2600 (voice and TDD). To file a complaint of discrimination, write to USDA, Director, Office of Civil Rights, 1400 Independence Avenue, S.W., Washington, D.C. 20250-9410, or call (800) 795-3272 (voice) or (202) 720-6382 (TDD). USDA is an equal opportunity provider and employer.

Ray G. Anderson

ray.anderson@ars.usda.gov

Jorge F. S. Ferreira

jorge.ferreira@ars.usda.gov

Dennise L. Jenkins

dennise.jenkins@ars.usda.gov

Nildo da Silva Dias

nildo@ufersa.edu.br to a potentially inaccurate $\mathrm{ET}_{0}$ for irrigation scheduling. In this study, we investigated multiple $\mathrm{ET}_{0}$ products from six meteorological stations, a satellite $\mathrm{ET}_{0}$ product, and integration (merger) of two stations' data in Southern California, USA. We evaluated $\mathrm{ET}_{0}$ against lysimetric ET observations from two lysimeter systems (weighing and volumetric) and two crops (wine grapes and Jerusalem artichoke) by calculating crop ET $\left(\mathrm{ET}_{\mathrm{c}}\right)$ using crop coefficients for the lysimetric crops with the different $\mathrm{ET}_{0} . \mathrm{ET}_{\mathrm{c}}$ calculated with $\mathrm{ET}_{0}$ products that incorporated field-specific wind speed had closer agreement with lysimetric ET, with RMSE reduced by 36 and $45 \%$ for grape and Jerusalem artichoke, respectively, with on-field anemometer data compared to wind data from the nearest station. The results indicate the potential importance of on-site meteorological sensors for $\mathrm{ET}_{0}$ parameterization; particularly where microclimates are highly variable and/or irrigation water is expensive or scarce.

\section{Introduction}

Globally, irrigation is the largest anthropogenic use of fresh water, consuming upwards of $70 \%$ of applied ('blue') water use (Rost et al. 2008). In many regions, water available for agricultural consumption has been significantly reduced due to numerous, and often concurrent, factors

Donald L. Suarez

donald.suarez@ars.usda.gov

1 Contaminant Fate and Transport Unit, US Salinity Laboratory, USDA-Agricultural Research Service, Riverside, CA, USA

2 Water Reuse and Remediation Unit, US Salinity Laboratory, USDA-Agricultural Research Service, Riverside, CA, USA 
(Falkenmark 2013) including drought (Hoekstra et al. 2012), ground water depletion (Scanlon et al. 2012), environmental preservation requirements (Petts 2009), and increased urban and industrial demands (Pritchett et al. 2008). Water availability is expected to continue to be constrained due to population growth and economic development (Vörösmarty et al. 2000), current unsustainable depletion of groundwater (Famiglietti 2014), and ongoing and future climate change (Elliott et al. 2014; Diffenbaugh et al. 2015). This reduction in agricultural water availability has led to increased fallowing of land (Connor et al. 2012; Christian-Smith et al. 2014) and the need of more efficient irrigation methods, including drip irrigation (Postel 2000; Gleick 2002; Ayars et al. 2015). The reduction in agricultural water has also led to substantial increase in water prices; farmers in the highest priced regions (e.g., Southern Coastal California, USA; Israel) pay $\sim \$ 1$ or more per $\mathrm{m}^{3}$ for the most expensive water (Howitt 2014; Ward and Becker 2015). Consumption of this expensive water can only be supported by high-value horticultural crops or landscapes (golf courses, parks, and sports fields) with extensive input costs; these same environments can be very susceptible to water stress (Delfine et al. 2001; Lopez et al. 2012) or may need precisely managed water stress to optimize crop quality (Chaves et al. 2007). This high cost of water, associated with risks of losses of valuable crops if water demand is inaccurately calculated, illustrates the need to precisely and accurately parameterize and forecast crop water demand.

One common approach for assessing crop water use is reference evapotranspiration $\left(\mathrm{ET}_{0}\right)$, combined with a coefficient based on vegetation cover characteristics (Jensen et al. 1970; Doorenbos and Pruitt 1977; Allen et al. 1998, 2005). Various ET equations such as the Hargreaves and Samani (1985), Makkink (1957), and Priestley and Taylor (1972) have been used as references. However, groups including the Food and Agriculture Organization (FAO) and the American Society of Civil Engineers (ASCE) have used almost identical versions of the Penman-Monteith equation (Allen et al. 1998, 2005). In this formulation, $\mathrm{ET}_{0}$ represents the meteorological demand for water over a hypothetical, wellwatered, short ( $12 \mathrm{~cm}$ tall) grass surface, with a parameterized surface albedo, leaf area index, and bulk canopy resistance. The FAO reference approach presented in Irrigation and Drainage paper 56 (Allen et al. 1998), hereafter referred to as FAO-56, has the advantage of considering ET driven both by radiation and by aerodynamic transport, the product of wind speed, and vapor pressure deficit which enhances evapotranspiration.

\footnotetext{
3 Department of Environmental and Technical Sciences, Federal Rural University of the Semi-Arid (UFERSA), Mossoró, Rio Grande Do Norte, Brazil
}

Although the FAO-56 Penman-Monteith approach is well suited for estimating $\mathrm{ET}_{0}$, it is one of the most dataintensive approaches (Valiantzas 2013), which can reduce the density of suitable meteorological stations. The low density of meteorological stations relative to the topographic and climatic variability in hilly Mediterranean regions often results in irrigated fields that have a different microclimate than the nearest reference ET station (Courault and Ruget 2001). Current practice is to apply a "microclimate adjustment coefficient" on top of the existing $\mathrm{ET}_{0}$ to calculate actual ET (Carrow 2006; Spano et al. 2009; Salvador et al. 2011; Nouri et al. 2013a, b; Snyder et al. 2015). However, this microclimate coefficient can be highly subjective and difficult to assess (Carrow 2006; Litvak and Pataki 2016) and can require substantial effort and resources to quantify at both local and regional scales (Snyder et al. 2015). Furthermore, while coefficients can be adjusted between seasons, this approach assumes that the microclimate coefficient remains constant on a daily and inter-annual basis. This is a questionable assumption given the variations in controls on microclimate, including the strength of land-sea breezes, coastal fog/clouds, and other climatic oscillations.

Recent advances in less expensive meteorological sensors (Han et al. 2008; Bitella et al. 2014; Chiang 2015) and data communications and processing infrastructure (Pierce and Elliott 2008) can reduce the costs for on-farm meteorological networks, and have the potential to provide improved, site-specific inputs for the FAO-56 $\mathrm{ET}_{0}$ equation. However, on-farm meteorological stations will most likely be situated over non-reference surfaces, which can result in significant errors in $\mathrm{ET}_{0}$ calculation, especially due to deviations in temperature and humidity from a lower or non-evapotranspiring surface (Temesgen et al. 1999). On-farm sensors can provide highly accurate observations of near surface wind speeds, which is a primary control on terrestrial evapotranspiration (McVicar et al. 2012) and is not currently observable at high spatial scales with satellite remote sensing. In this study, we assess the potential to integrate field-specific meteorological observations with data from more remote reference ET sites and/or satellite products to calculate $\mathrm{ET}_{0}$ more accurately and without incorporating additional microclimate coefficients. We compare lysimetric ET observations from two crops and lysimeter types against a calculated crop ET $\left(\mathrm{ET}_{\mathrm{c}}\right)$ using crop coefficients and multiple $\mathrm{ET}_{0}$ products, including a local weather station with FAO-56 and two other reference ET equations, five reference ET stations located at varying distances from our field, a merged reference ET product that contains wind speed data from the local station and air temperature and relative humidity data from the closest reference ET station, and a satellite-based reference ET product. We also conduct an inter-comparison of $\mathrm{ET}_{0}$ in two climatically and topographically different regions of California, Monterey Bay area, and Sonoma Valley, to assess 
Table 1 Site characteristics are presented for lysimeter sites, non-reference weather station (USSL), and local CIMIS weather stations

\begin{tabular}{|c|c|c|c|c|c|c|}
\hline $\begin{array}{l}\text { Station/field name (code name and } \\
\text { CIMIS number) }\end{array}$ & Latitude $\left({ }^{\circ} \mathrm{N}\right)$ & Longitude $\left({ }^{\circ} \mathrm{W}\right)$ & Elevation (m) & $\begin{array}{l}\text { Distance from } \\
\text { USSL }(\mathrm{km})\end{array}$ & $\begin{array}{l}\text { Distance from } \\
\text { coast }(\mathrm{km})\end{array}$ & $\begin{array}{l}\text { Topo- } \\
\text { graphic } \\
\text { obstacle }\end{array}$ \\
\hline USSL weather station (WS) & 33.974066 & 117.319490 & 344 & & 65 & Yes \\
\hline USSL grape field lysimeters & 33.973955 & 117.319885 & 344 & & 65 & Yes \\
\hline USSL Jerusalem artichoke lysimeters & 33.972916 & 117.319907 & 349 & & 65 & Yes \\
\hline UCR CIMIS WS (UCR \#44) & 33.964942 & 117.336980 & 320 & 1.9 & 64 & Yes \\
\hline Moreno Valley CIMIS WS (MV \#238) & 33.90 & 117.17 & 501 & 16.1 & 68 & Yes \\
\hline Perris-Menifee CIMIS WS (PM \#240) & 33.76 & 117.20 & 430 & 26.2 & 54 & Yes \\
\hline Winchester CIMIS WS (WI\#179) & 33.663325 & 117.09338 & 443 & 40.3 & 53 & Yes \\
\hline Pomona CIMIS WS (PO \#78) & 34.056589 & 117.81307 & 220 & 46.5 & 44 & No \\
\hline
\end{tabular}

Selected stations were within $50 \mathrm{~km}$ and $200 \mathrm{~m}$ elevation of USSL. All coordinates are reported in the WGS84 datum. Distance to coast is straight distance to closest coast. "Topographic obstacle" is defined as a ridge or mountain along the line between the station and closest coast that is at least $400 \mathrm{~m}$ in elevation higher than the station elevation

the sensitivity of $\mathrm{ET}_{0}$ to wind input. The results illustrate the potential for a combination of reference surface and local meteorological data to improve the accuracy of $\mathrm{ET}_{\mathrm{c}}$ calculation, thereby permitting easier irrigation scheduling in most water balance-based programs.

\section{Materials and methods}

\section{Local reference evapotranspiration meteorological data}

The local study was conducted at and near the United States Salinity Laboratory (USSL) in Riverside, California, USA, using six meteorological stations (Table 1; Fig. 1), a satellite-based reference evapotranspiration $\left(\mathrm{ET}_{0}\right)$ product, and two lysimeter facilities to observe crop water use. The meteorological stations were compared over a 1 year period (1 June 2014 to 31 May 2015) and were selected due to their distance $(<50 \mathrm{~km})$ and elevation (less than $200 \mathrm{~m}$ difference) from USSL. Five of the weather stations (UCR, Moreno Valley, Perris-Menifee, Winchester, and Pomona) were in the California Irrigation Management and Information System (CIMIS), and the satellite-based product was Spatial CIMIS $\left(4 \mathrm{~km}^{2}-2 \mathrm{~km} \times 2 \mathrm{~km}\right.$ pixels). Details about the CIMIS and Spatial CIMIS network, instrumentation, algorithms, and processing are reported elsewhere (Eching et al. 1998; Hart et al. 2009). CIMIS measures wind speed with a cup anemometer (Model 014, Met One Instruments Inc., Grants Pass, Oregon, USA) that had a cut-out velocity of $0.45 \mathrm{~m} \mathrm{~s}^{-1}$ and accuracy of $1.5 \%$. Spatial CIMIS relies on satellite parameterization of solar irradiance combined with elevation-corrected interpolation of ground-based meteorological variables (wind speed, humidity, and temperature) between CIMIS stations to determine Spatial CIMIS ET . $_{0}$. Spatial CIMIS $\mathrm{ET}_{0}$ interpolation is designed to avoid overfitting interpolated fields to the closest station (Hart et al.
2009). Thus, at USSL, the Spatial CIMIS meteorological fields will be influenced by multiple close stations including UCR, Moreno Valley, and Perris. The five CIMIS stations were located at varying distances (44-68 km) away from the coast and all except one station, Pomona, had a topographic obstruction at least $400 \mathrm{~m}$ in height between the station and coast (Table 1). At each station, the standard CIMIS station $\mathrm{ET}_{0}$ instruments (air temperature/relative humidity, solar irradiance, and anemometer) are located on a well-watered and maintained grass field at $2 \mathrm{~m}$ height. For the CIMIS stations, we used the daily meteorological observations and the $\mathrm{ET}_{0}$ calculated using the Penman-Monteith equation as formulated in FAO-56.

A local meteorological station (USSL WS) consisted of a weather station installed at the US Salinity Laboratory, adjacent to a small ( $\sim .1$ ha) research vineyard. USSL WS sits on bare soil that is identical to the soil surface for the research vineyard and lysimeters. Like much of Southern California agriculture, the USSL WS sits in a complex

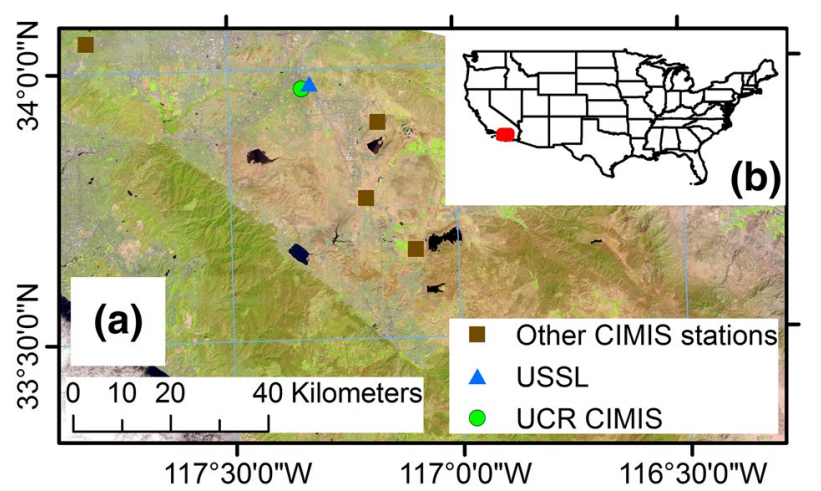

Fig. 1 Maps of study site: a Landsat 8 false color image of Southern California illustrating the location of USSL and the CIMIS stations in relation to each other. b Map of United States with extent of a indicated by red box. (Color figure online) 
topographic environment with surrounding hills or mountains on three sides (north, south, and east) of the field and research station, relatively small fields, and tree breaks. Instrumentation on the USSL WS station included a pyranometer (SP110, Apogee Instruments, Logan, Utah, USA ${ }^{1}$ ), incoming photosynthetically active radiation (quantum) sensor (Licor 190, Licor Inc., Lincoln, Nebraska), two-dimensional sonic anemometer (Windsonic, Gill Instruments Ltd., Lymington, UK), an integrated air temperature and relative humidity probe (HC2S3, Rotronic USA, Fountain Valley, California, USA), soil temperature (TCAV, Campbell Scientific Inc., Logan, Utah, USA) observations at three depths $(10,30$, and $50 \mathrm{~cm})$, and a tipping bucket rain gauge (TE525, Texas Electronics, Dallas, Texas, USA). Solar radiation, air temperature/relative humidity, and the sonic anemometer were all located at $2 \mathrm{~m}$ height. Data from USSL WS were stored and processed on a solid-state data logger (CR1000, Campbell Scientific, Inc.) into $30 \mathrm{~min}$ and daily values for input into the FAO-56 model. For our analyses and comparison with CIMIS, we calculated all equations at USSL WS on a daily time step. We used the FAO-56 approach (Allen et al. 1998) for calculating net radiation from solar radiation and other meteorological data and held the parameterized albedo at 0.23 . Along with the FAO-56, we also used two non-aerodynamic transport compensating ET equations at the USSL WS, Hargreaves and Samani (1985) and Priestley and Taylor (1972). For Priestley-Taylor, we chose the default empirical coefficient $(\alpha)$ of 1.26 , as proposed by Priestley and Taylor (1972) for well-watered surfaces. $\alpha=1.26$ is widely used in hydrological studies (McMahon et al. 2013). We selected these two equations as many specialty-crop farmers may already have temperature and humidity sensors in their fields for frost protection (Pierce and Elliott 2008).

Along with the existing $\mathrm{ET}_{0}$ products, we developed a merged $\mathrm{ET}_{0}$ product (UCR merged) that combines meteorological inputs from both the UCR CIMIS (solar radiation, air temperature, and humidity) and from the USSL WS (wind speed) stations. We reasoned that using a local wind input would address the high spatial variability of wind with changing topography and surface roughness (Ruel et al. 1998; Conil and Hall 2006). Furthermore, air temperature and humidity are the observations which we would expect to be affected by a non-reference surface, so we reasoned that using the UCR CIMIS air temperature and relative humidity would result in an $\mathrm{ET}_{0}$ calculation that would be more reflective of a reference surface at that specific location, resulting in improved calculation of crop ET $\left(\mathrm{ET}_{\mathrm{c}}\right)$. Finally, we used

\footnotetext{
${ }^{1}$ Mention of trade names or commercial products in this publication is solely for the purpose of providing specific information and does not imply recommendation or endorsement by the U.S. Department of Agriculture.
}

the solar radiation sensor from UCR CIMIS as incoming solar radiation will likely have less spatial variation than the other meteorological parameters. In addition, incoming solar radiation can be well estimated from satellite observations for calculating $\mathrm{ET}_{0}$ (Hart et al. 2009). Reducing local field instrumentation to just a sonic anemometer would have two major advantages. First, the overall initial instrumentation cost would decrease substantially without a local pyranometer or temperature/relative humidity sensor (decrease of $\$ 500$ to more than $\$ 1000$ USD depending upon sensor quality). Second, and perhaps more importantly, using only a two-dimensional sonic anemometer (cost of $\sim \$ 1000$ USD or less) could significantly reduce the farmer/irrigator's effort and cost to quality control and calibrate field observations. Most sonic anemometers do not require periodic calibration, unlike temperature, relative humidity, and solar radiation sensors that often require annual calibration by outside vendors, or cup anemometers that can require bearing replacement or factory overhaul every 12-36 months. Multiple commercial sonic anemometers exist that can be integrated with existing field hardware for monitoring soil moisture and other field conditions, thus avoiding another cost for additional data recording and transmitting equipment. Finally, maintenance is often limited to basic cleaning of transducers and ensuring the sonic pathway remains clear of obstructions (e.g. spider webs).

For all daily meteorological observations and reference ET calculations, we assessed statistical significance using bootstrapping to determine the annual mean and confidence interval for each variable due to the presence of temporal autocorrelation (Eskridge et al. 1997). We used 10,000 annual simulations with replacement for each climate variable and resulting reference ET calculation.

\section{Lysimeter evapotranspiration validation data and parameterized ET}

We used two lysimeter systems and two crops to evaluate the performance of the three reference ET products. One system, the weighing lysimeter, derives crop ET directly by measuring the change in mass of an isolated soil column. The ten weighing lysimeters constructed for this experiment each consisted of an inner steel shell, an outer polypropylene shell, a drain system, and a suspended load cell weighing system. A $208 \mathrm{~L}$ (55 gallon) steel drum, $57.15 \mathrm{~cm}$ inside diameter, with a vacuum drain system was used as the inner shell; each individual drum to contain one wine grape vine (Cabernet Sauvignon) with a vertical shoot position trellis independent of other vines. A suspended load cell weighing system, crane scale, was inserted between the winch and drum sling to weigh the inner steel drums. A commercial crane scale, NC-1 (CAS scale USA cooperation, East Rutherford, New Jersey, USA) was used as the suspended 
load cell to determine the change in mass of each lysimeter. The NC- 1 scale, $400 \pm 0.2 \mathrm{~kg}$, was ISO and ANSI certified for accuracy in both extreme temperature and weather conditions. Records were kept of all mass inputs and output from the lysimeter such as applied irrigation water, extracted drainage water, and vegetative material removed by pruning and grape harvest. ET was calculated as a residual of inputs, outputs, and mass change. The 10 lysimeters were spaced in two rows of five drums, with $2.5 \mathrm{~m}$ separation between the rows and $2 \mathrm{~m}$ between each vine within a row. This spacing matched the planting density of the experimental vineyard; like the vineyard vines, there was bare soil in between each of the lysimeter barrels. Each lysimeter was irrigated once or twice a week by hand, with the applied watering consisting of the previous week's ET. Beginning in mid-2014, the fraction of light interception and Leaf Area Index (LAI) of the lysimeters was determined weekly using ceptometer observations of Leaf Area Density and measurements of canopy width (Accupar LP-80, Decagon Devices, Pullman, Washington, USA). The fraction of light interception was used to predict vine $K_{\mathrm{c}}$ following the $K_{\mathrm{c}}-$ light interception relationships for grape vines reported by Williams and Ayars (2005). We used this $K_{\mathrm{c}}$ value to predict crop ET using the various $\mathrm{ET}_{0}$ calculations and compared the computed $\mathrm{ET}_{\mathrm{c}}$ to measured ET. Measured ET volumes were averaged to the spacing per vine $\left(5 \mathrm{~m}^{2} /\right.$ vine $)$ rather than the lysimeter area $\left(0.26 \mathrm{~m}^{2} / \mathrm{vine}\right)$ for areal calculations due to the canopy extending beyond the lysimeter boundaries. We note that these vines were small, young wine vines with wide spacing which accounts for the relatively low measured ET and calculated $\mathrm{ET}_{\mathrm{c}}$ when expressed on an areal basis.

The second lysimeter system is a sand tank lysimeter system (STLS) connected to water reservoirs. Full details on the large sand tanks and the hydrologic properties of the sand media are reported elsewhere (Wang 2002; Poss et al. 2010; Cornacchione and Suarez 2015; Ors and Suarez 2016). This study used ET data from the control salinity treatments of Dias et al. (2016), and full details of the experiment are reported there. The STLS has 24 large, outdoor sand tanks $(3 \mathrm{~m} \times 1.5 \mathrm{~m} \mathrm{~W} \times 2 \mathrm{~m} \mathrm{D}$ with 1.58 and $2.7 \mathrm{~m}$ spacing between each lysimeter) connected to $3810 \mathrm{~L}$ recirculating water reservoirs. The STLS was planted with three cultivars (Stampede, White Fuseau, and Red Fuseau) of Jerusalem artichoke (Helianthus tuberosus) on 29 April 2014, with tuber harvest on 4 September (Stampede), 2 October (White Fuseau), and 8 October (Red Fuseau). To avoid confounding the evaluation of calculated $\mathrm{ET}_{c}$, we limited our analysis to the three tanks with control salinity [irrigation water electrical conductivity $\left(\mathrm{EC}=1.2 \mathrm{dS} \mathrm{m}^{-1}\right)$ ] to avoid salt stress, which would reduce the crop coefficient below the non-stressed crop coefficient which we used to calculate $\mathrm{ET}_{\mathrm{c}}$. We used four observation dates from the Jerusalem artichoke (Table 2), which occurred after apparent full
Table 2 Lysimeter weight/volume observation dates for mid-period ET for grape and Jerusalem Artichoke sites, along with the estimated $K_{\mathrm{c}}$ for each date

\begin{tabular}{llll}
\hline Grape & Grape $K_{\mathrm{c}}$ & Jerusalem Artichoke & Artichoke $K_{\mathrm{c}}$ \\
\hline 13 June 2014 & 0.065 & 18 June 2014 & 1.33 \\
20 June 2014 & 0.070 & 28 June 2014 & 1.33 \\
27 June 2014 & 0.075 & 08 July 2014 & 1.33 \\
3 July 2014 & 0.080 & 23 July 2014 & 1.33 \\
11 July 2014 & 0.081 & & \\
18 July 2014 & 0.111 & & \\
25 July 2014 & & & \\
28 July 2014 & 0.119 & & \\
11 August 2014 & 0.096 & & \\
\hline
\end{tabular}

Procedures to determine $K_{\mathrm{c}}$ are discussed in "Lysimeter evapotranspiration validation data and parameterized ET". Lysimeter observations from the grape field for the period ending 25 July 2014 (bolded date) were not used due to substantial missing data from the UCR CIMIS station

canopy cover was obtained. We validated this assumption by checking to see if there were any trends in apparent $K_{\mathrm{c}}$ during the study and by comparing the ET observations with plant canopy height. While a formal literature value of $K_{\mathrm{c}}$ has not been published for Jerusalem artichoke, multiple researchers (Monti et al. 2005; Ruttanaprasert et al. 2016) have used measured sunflower (Helianthus annuus) $K_{\mathrm{c}}$ to parameterize ET due to similar plant morphology between sunflower and Jerusalem artichoke; thus, we use midperiod $K_{\mathrm{cb}}\left(K_{\mathrm{cb}}=1.00\right)$ to estimate $K_{\mathrm{c}}($ Lamm et al. 2010). The STLS tanks are elevated and are surrounded by nonvegetated gravel and concrete, and thus are exposed to the "clothesline" effect, resulting in high ET and $K_{\mathrm{c}}$ (Skaggs et al. 2006); therefore, we multiplied the literature sunflower $K_{\mathrm{c}}$ value by 1.33 following the ratio of observed to the literature alfalfa $K_{\mathrm{c}}$ for the STLS observed in early summer (Skaggs et al. 2006). Each Jerusalem artichoke observation period was 10 days, with the exception of the period ending 23 July 2014, which was 15 days long. Each grape observation period was 7 days ( 1 week) with the exceptions of the period ending 28 July 2014 (3 days) and 11 August 2014 (14 days) (Table 2).

\section{Regional reference evapotranspiration wind sensitivity}

To evaluate the sensitivity of the FAO-56 $\mathrm{ET}_{0}$ equation across different microclimates, we conducted an evaluation with both the local CIMIS stations in Inland Southern California (Table 1) and CIMIS stations from two other regions of California with differing microclimates, the Sonoma Valley in Northern California, and the Monterey Bay area along the Central Coast (Table 3). Both the Sonoma Valley and Monterey Bay regions are heavily agricultural, but Monterey 
Table 3 Information about CIMIS stations used in extended comparison of impacts of wind speed heterogeneity on $\mathrm{ET}_{0}$

\begin{tabular}{lllll}
\hline Station (CIMIS number) & Latitude $\left({ }^{\circ} \mathrm{N}\right)$ & Longitude $\left({ }^{\circ} \mathrm{W}\right)$ & Elevation $(\mathrm{m})$ & Region \\
\hline Castroville (\#19) & 36.768167 & 121.773640 & 3 & Monterey Bay \\
De Laveaga (\#104) & 36.997444 & 121.996760 & 91 & Monterey Bay \\
Green Valley Road (\#111) & 36.943964 & 121.763940 & 34 & Monterey Bay \\
Salinas North (\#116) & 36.716806 & 121.691890 & 19 & Monterey Bay \\
Pajaro (\#129) & 36.902778 & 121.741930 & 20 & Monterey Bay \\
Pacific Grove (\#193) & 36.633222 & 121.934860 & 15 & Monterey Bay \\
Watsonville West II (\#209) & 36.913083 & 121.823650 & 73 & Monterey Bay \\
Carmel (\#210) & 36.540889 & 121.881960 & 23 & Monterey Bay \\
Laguna Seca (\#229) & 36.570111 & 121.7865 & 98 & Monterey Bay \\
Santa Rosa (\#83) & 38.403550 & 122.799930 & 24 & Sonoma Valley \\
Windsor (\#103) & 38.526650 & 122.813758 & 28 & Sonoma Valley \\
Petaluma East (\#144) & 38.266428 & 122.616460 & 30 & Sonoma Valley \\
Bennett Valley (\#158) & 38.419439 & 122.658720 & 82 & Sonoma Valley \\
\hline
\end{tabular}

Stations were grouped into two regions with different microclimates (Monterey Bay and Sonoma Valley) for inter-comparison with each other
Bay has a cooler, coastal climate, while Sonoma Valley is inland and has less marine influence. For Monterey Bay, we used nine CIMIS stations that were within $10 \mathrm{~km}$ of the coast, while for Sonoma, we used four stations that were relatively close to each other and away from the mouth of the valley that would be heavily influenced by San Francisco Bay. For both regions, we used the same time period (1 June 2014 to 31 May 2015) as for Southern California.

For the three regions, we evaluated the sensitivity of wind inputs using the non-wind meteorological data and then inputting the wind speed from each of the other stations in the same region. We then calculated the $\mathrm{ET}_{0}$ with the merged wind speed and compared this $\mathrm{ET}_{0}$ to the $\mathrm{ET}_{0}$ with the local station wind. We calculated the RMSE between the each station-wind combination to assess the error introduced with using another station's wind data. We also evaluated the impact of aerodynamic transport on $\mathrm{ET}_{0}$ by comparing monthly sums of Priestley-Taylor $\mathrm{ET}_{0}$ compared to FAO$56 \mathrm{ET}_{0}$.

\section{Results}

\section{Assessment of meteorological and reference ET differences}

Over the annual inter-comparison, daily mean air temperature (Air $T$-Fig. 2a), incoming solar radiation $\left(R_{\mathrm{s}}\right.$ Fig. 2c), and relative humidity (RH-Fig. 2d) were similar between the UCR CIMIS and USSL WS meteorological stations, while wind speed ( $U$-Fig. 2b) showed larger differences. Over the entire year, mean $\pm 95 \%$ confidence interval of Air $T$ was $19.0 \pm 0.5^{\circ} \mathrm{C}$ at the UCR CIMIS station and $19.7 \pm 0.5{ }^{\circ} \mathrm{C}$ at USSL WS. Solar radiation was also not statistically different between the sites, with mean daily $R_{\mathrm{s}}$ of $19.8 \pm 0.8 \mathrm{MJ} \mathrm{m}^{-2} \mathrm{day}^{-1}$ at UCR CIMIS and $18.8 \pm 0.7 \mathrm{MJ} \mathrm{m}^{-2}$ day $^{-1}$. With respect to the other CIMIS sites, air temperature was not statistically different at Pomona $\left(18.3 \pm 0.5^{\circ} \mathrm{C}\right)$, Moreno Valley $\left(19.1 \pm 0.6{ }^{\circ} \mathrm{C}\right)$, or Perris-Menifee $\left(18.3 \pm 0.6^{\circ} \mathrm{C}\right)$, and was lower at Winchester $\left(17.6 \pm 0.5{ }^{\circ} \mathrm{C}\right)$. Solar radiation for the other sites (data not shown) and Spatial CIMIS $\left(20.0 \pm 0.7 \mathrm{MJ} \mathrm{m}^{-2} \mathrm{day}^{-1}\right)$ was not significantly different from UCR CIMIS and USSL WS. Relative humidity was significantly different between UCR CIMIS and USSL WS, with UCR having an annual mean RH of $48.4 \pm 1.7 \%$ and USSL $54.2 \pm 1.8 \%$. With respect to the other stations, the Moreno Valley and Perris-Menifee stations were statistically the same as UCR CIMIS (data not shown), while the Winchester and Pomona stations had the highest mean RH (both 62\%). However, the largest differences among stations were with wind speed. For example, UCR CIMIS annual mean wind speed was $1.78 \pm 0.05 \mathrm{~m} \mathrm{~s}^{-1}$, while wind speed at USSL WS was only approximately $50 \%$ of UCR CIMIS at $0.93 \pm 0.02 \mathrm{~m} \mathrm{~s}^{-1}$, which is consistent with the relatively more sheltered location of USSL WS compared to the UCR CIMIS station. The other CIMIS stations also showed greater variation in wind speed (Moreno Valley - $1.74 \pm 0.07 \mathrm{~m} \mathrm{~s}^{-1}$; Perris-Menifee-2.01 $\pm 0.07 \mathrm{~m} \mathrm{~s}^{-1}$; Winchester $-2.19 \pm 0.07 \mathrm{~m} \mathrm{~s}^{-1}$; and Pomona $-1.00 \pm 0.02 \mathrm{~m} \mathrm{~s}^{-1}$;) with no apparent relationship to coastal distance. Only the Moreno Valley and Pomona stations were statistically similar to UCR CIMIS and USSL WS, respectively.

Largely due to its higher wind speed, the UCR CIMIS station had a higher $\mathrm{ET}_{0}$ than the USSL WS station (Fig. 3a), with UCR CIMIS ET $\mathrm{ET}_{0}$ averaging $4.53 \pm 0.20 \mathrm{~mm} \mathrm{day}^{-1}$ and USSL WS $\mathrm{ET}_{0}$ averaging $3.65 \pm 0.17 \mathrm{~mm} \mathrm{day}^{-1}$, with the range again indicating the $95 \%$ confidence interval about the 
Fig. 24 panel figure of daily mean air temperature (a), wind speed (b), incoming solar radiation (c), and relative humidity (d) from the UCR CIMIS and USSL WS meteorological stations. Solar radiation from the Spatial CIMIS algorithm is also shown on $\mathbf{c}$
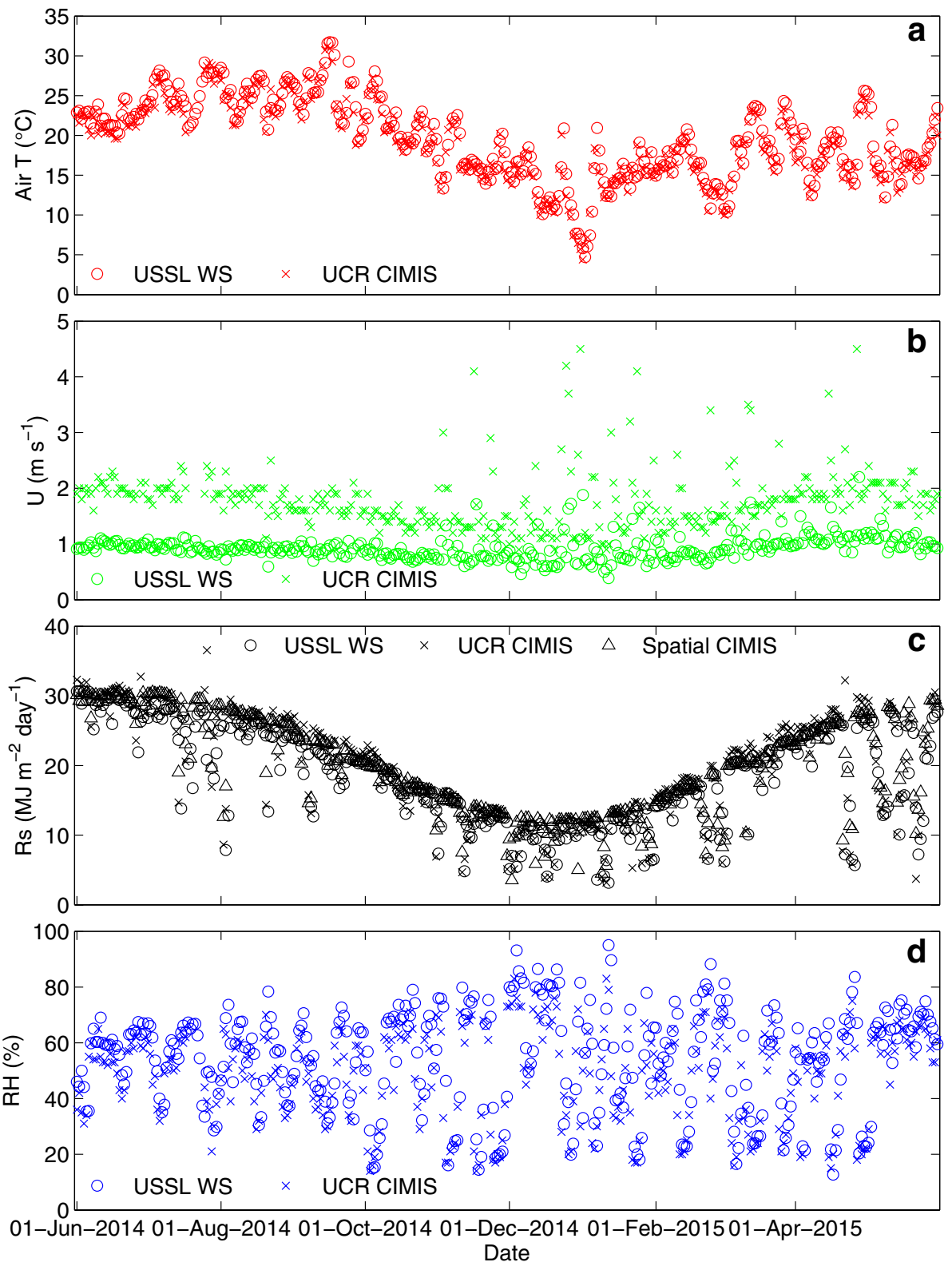

mean. The UCR merged product that replaced the UCR station wind using the USSL WS wind speed had a mean daily $\mathrm{ET}_{0}$ of $3.62 \pm 0.17 \mathrm{~mm} \mathrm{day}^{-1}$, very close to the value from the USSL WS ET $0\left(3.65 \pm 0.17 \mathrm{~mm} \mathrm{day}^{-1}\right)$. The mean daily

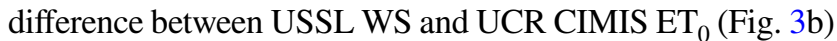
was $-0.92 \pm 0.11 \mathrm{~mm} \mathrm{day}^{-1}$, while the difference between UCR merged and UCR CIMIS was similar but less variable $\left(-0.91 \pm 0.08 \mathrm{~mm} \mathrm{day}^{-1}\right)$, indicating that the differences in wind speed were more important than relative humidity for driving $\mathrm{ET}_{0}$. When regressed against each other, the UCR CIMIS and USSL WS ET 0 have a strong relationship (Fig. 4; Table 4), with a slope of 0.7 and an intercept of less than $0.5 \mathrm{~mm}$ day $^{-1}$. The relative differences between UCR CIMIS and USSL WS $\mathrm{ET}_{0}$ were larger at higher $\mathrm{ET}_{0}$. As expected, the UCR merged product had better agreement with UCR
CIMIS, including a slope closer to 1, intercept that was not significantly different than 0 and a higher coefficient of determination $\left(r^{2}\right)$ and lower root-mean-squared error than USSL WS (Table 4). Over the entire year, the sum of $\mathrm{ET}_{0}$ for the UCR CIMIS, UCR merged, and USSL WS products was 1622,1278 , and $1308 \mathrm{~mm}$, respectively.

With respect to the other CIMIS stations and $\mathrm{ET}_{0}$ products, Spatial CIMIS $\left(4.36 \pm 0.19 \mathrm{~mm} \mathrm{day}^{-1}\right)$, Moreno Valley $\left(4.37 \pm 0.20 \mathrm{~mm} \mathrm{day}^{-1}\right)$, Perris-Menifee $\left(4.54 \pm 0.20 \mathrm{~mm} \mathrm{day}^{-1}\right)$, Winchester $\left(4.27 \pm 0.21 \mathrm{~mm} \mathrm{day}{ }^{-1}\right), t$, and weather station Hargreaves-Samani $\left(4.47 \pm 0.20 \mathrm{~mm} \mathrm{day}^{-1}\right)$ were all similar to the UCR CIMIS, while the weather station Priestley-Taylor $\left(3.28 \pm 0.19 \mathrm{~mm} \mathrm{day}^{-1}\right)$ was lower. Among the CIMIS stations, only Pomona $\left(3.63 \pm 0.17 \mathrm{~mm} \mathrm{day}^{-1}\right)$ was 
Fig. 3 Reference ET (ET $)$ for the four products (a) and difference between the USSL WS, UCR merged, and Spatial CIMIS products and the UCR CIMIS Penman-Monteith reference ET (b) for the yearly inter-comparison
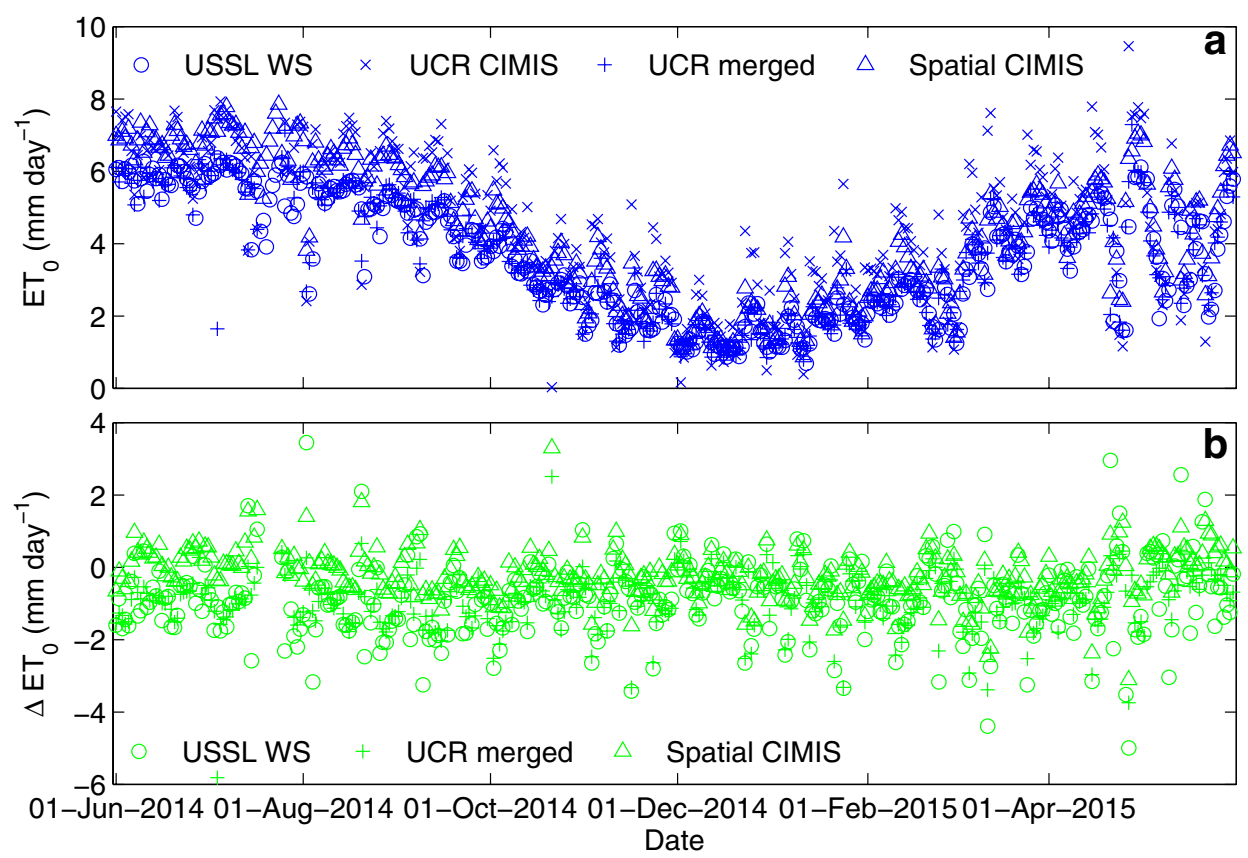

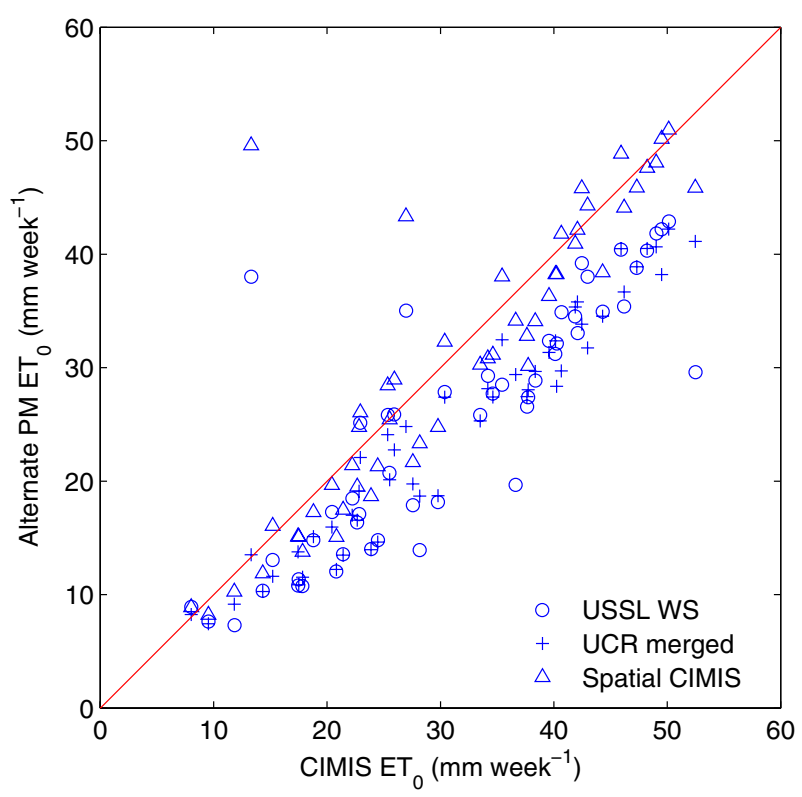

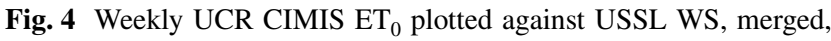
and Spatial CIMIS $\mathrm{ET}_{0}$

significantly lower, likely due to its closer coastal proximity with fewer topographic obstructions. When compared on a weekly basis, more substantial differences begin to emerge between the $\mathrm{ET}_{0}$ products and locations (Table 4). The nonaerodynamic transport compensating reference ET equations at the USSL WS (Hargreaves-Samani and Priestley-Taylor) had poor agreement with UCR CIMIS as illustrated by their lowest $r^{2}$, high RMSE for Hargreaves-Samani, and most uncertainty in the slope and $y$-intercept of all of the intercompared products. The CIMIS stations and merged $\mathrm{ET}_{0}$ all had high $r^{2}>0.9$, and CIMIS Pomona and merged $\mathrm{ET}_{0}$ had the lowest RMSE of less than $3 \mathrm{~mm}$ week $^{-1}$. Annual $\mathrm{ET}_{0}$ for the other stations and products ranged from a low of $1300 \mathrm{~mm}$ (Pomona) to a high of $1627 \mathrm{~mm}$ (Perris-Menifee).

\section{Calculated crop ET with different $\mathrm{ET}_{0}$ compared to lysimeter ET}

The calculated grape vine $\mathrm{ET}_{\mathrm{c}}$ with the Williams and Ayars (2005) coefficients (Table 2) showed substantial variation against measured lysimeter ET depending upon the $\mathrm{ET}_{0}$ used (Fig. 5; Table 5). $\mathrm{ET}_{\mathrm{c}}$ calculated using the USSL WS and UCR merged $\mathrm{ET}_{0}$ had the closest agreement with a mean difference of 0.12 and $0.01 \mathrm{~mm}_{\text {period }}{ }^{-1}$, respectively, and the lowest RMSE (RMSE $<0.65 \mathrm{~mm}_{\text {period }}{ }^{-1}$ ). Priestly-Taylor had comparable RMSE and CV to the USSL WS and UCR merged $\mathrm{ET}_{0}$. Spatial CIMIS and Hargreaves-Samani had the highest RMSE (RMSE $>1.15 \mathrm{~mm}_{\text {period }}{ }^{-1}$ ) and differences in mean ET of over $0.8 \mathrm{~mm}_{\text {period }}{ }^{-1}$. CIMIS stations further away from USSL had varying RMSE, but all four other stations had mean $\mathrm{ET}_{\mathrm{c}}$ that was more than $15 \%$ higher than measured lysimeter ET. When assessed with a linear regression, the $\mathrm{ET}_{\mathrm{c}}$ calculated with the UCR merged product had the slope closest to 1 (slope $=0.90$ ), and the calculations with UCR merged and USSL WS $\mathrm{ET}_{0}$ were the only $\mathrm{ET}_{\mathrm{c}}$ calculations whose slope was not significantly different than 1 (regression not shown).

As expected from the dense vegetation cover and elevated position of the STLS, measured ET was much higher than for 
Table 4 Regression statistics equations (slope, $y$-intercept), coefficients of determination $\left(r^{2}\right)$, and root-mean-squared error (RMSE) for data presented in Fig. 4 and for other CIMIS stations and weekly data products not plotted on Fig. 4

\begin{tabular}{|c|c|c|c|}
\hline Compared reference ET & Slope & $y$-intercept & RMSE \\
\hline UCR CIMIS ET -USSL WS ET $_{0}$ & $0.75 \pm 0.13$ & $1.69 \pm 4.450 .72$ & 5.63 \\
\hline UCR CIMIS $\mathrm{ET}_{0}$-UCR merged $\mathrm{ET}_{0}$ & $0.82 \pm 0.05$ & $-1.15 \pm 1.910 .94$ & 2.42 \\
\hline UCR CIMIS ET -Spatial CIMIS ET $_{0}$ & $0.90 \pm 0.15$ & $2.48 \pm 4.940 .75$ & 6.58 \\
\hline UCR CIMIS $\mathrm{ET}_{0}$-USSL WS Hargreaves-Samani $\mathrm{ET}_{0}$ & $0.89 \pm 0.17$ & $3.51 \pm 5.570 .69$ & 7.13 \\
\hline UCR CIMIS $\mathrm{ET}_{0}$-USSL WS Priestley-Taylor $\mathrm{ET}_{0}$ & $0.80 \pm 0.17$ & $-2.683 .70 \pm 5.800 .64$ & 3.13 \\
\hline UCR CIMIS ET -Moreno CIMIS ET $_{0}$ & $0.93 \pm 0.04$ & $0.90 \pm 1.300 .98$ & 6.14 \\
\hline UCR CIMIS ET -Perris CIMIS ET $_{0}$ & $1.09 \pm 0.05$ & $-2.59 \pm 1.760 .97$ & 7.76 \\
\hline UCR CIMIS ET -Winchester CIMIS ET $_{0}$ & $1.02 \pm 0.07$ & $-2.47 \pm 2.180 .95$ & 5.87 \\
\hline UCR CIMIS ET ${ }_{0}$-Pomona CIMIS ET ${ }_{0}$ & $0.84 \pm 0.05$ & $-1.34 \pm 1.110 .98$ & 2.47 \\
\hline
\end{tabular}

Unless otherwise specified, $\mathrm{ET}_{0}$ refers to FAO-56 Penman-Monteith $\mathrm{ET}_{0}$

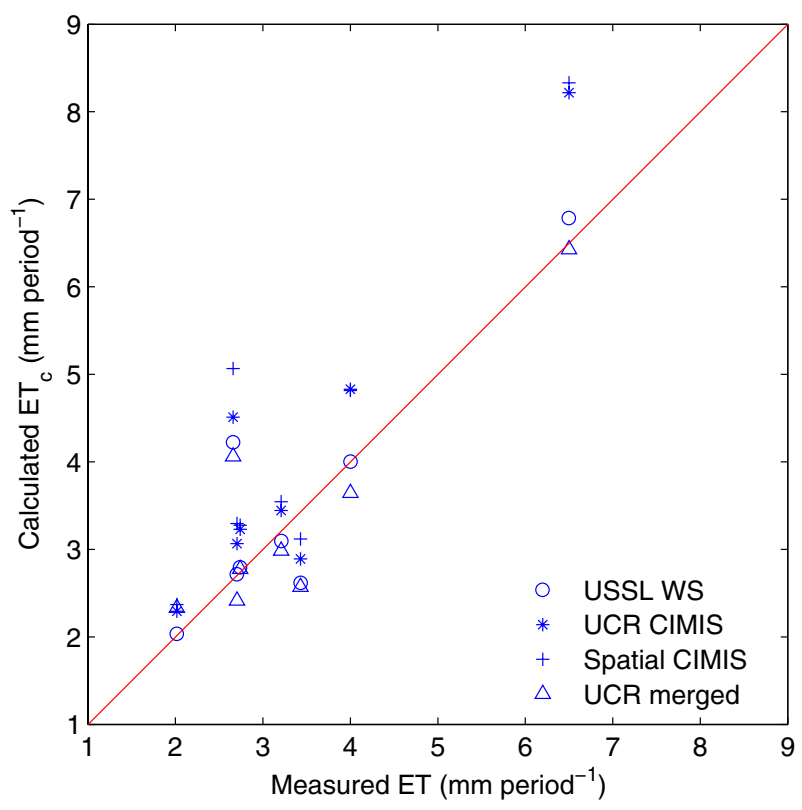

Fig. 5 Measured versus calculated evapotranspiration (ET) for the grape lysimeters. Calculated $\mathrm{ET}\left(\mathrm{ET}_{\mathrm{c}}\right)$ was determined using the different $\mathrm{ET}_{0}$ products multiplied by the crop coefficient following Williams and Ayars (2005). Line on graph is 1:1 line

the grape lysimeters at $92.8 \mathrm{~mm}_{\text {period }}{ }^{-1}$ (Table 5; Fig. 6). Like the grape lysimeter, the mean calculated $\mathrm{ET}_{\mathrm{c}}$ using the merged $\mathrm{ET}_{0}$ product and the Pomona CIMIS station were very close to measured ET (less than $0.5 \mathrm{~mm}_{\text {period }}{ }^{-1}$ difference). There was substantial variance between the measured ET and calculated $\mathrm{ET}_{\mathrm{c}}$ at higher ET rates (Fig. 6), with the highest measured ET coming in the first and last observation periods. Unlike the grape lysimeters, the local weather station-based products had the lowest coefficient of variation for the Jerusalem artichoke. The local FAO-56 and Priestley-Taylor calculations from the weather station had the lowest RMSE at 22.1 and $23.5 \mathrm{~mm}_{\text {period }}{ }^{-1}$, respectively, while all other stations had RMSE over $30 \mathrm{~mm}_{\text {period }}{ }^{-1}$. Also of particular note is the substantially higher $\mathrm{ET}_{\mathrm{c}}$ calculated with the UCR CIMIS and Spatial CIMIS stations (18 and $32 \mathrm{~mm}$ period $^{-1}$ higher than measured ET, respectively).

\section{Sensitivity of $\mathbf{E T}_{0}$ to wind input in different climatic regions}

In Inland Southern California, there was no clear relationship between distance between CIMIS stations and the accuracy of $\mathrm{ET}_{0}$ estimation using an alternate station's wind data (Table 6). Across all of the combinations of CIMIS stations and wind inputs, RMSE ranged from 0.33 to $0.98 \mathrm{~mm} \mathrm{day}^{-1}$. Moreno Valley had the highest error when using other stations' wind data with mean RMSE of $0.76 \mathrm{~mm} \mathrm{day}^{-1}$, while Pomona had the lowest RMSE at $0.44 \mathrm{~mm} \mathrm{day}^{-1}$. All the stations except Moreno Valley had the lowest RMSE with a station that was not the next closest. In particular, Winchester and Perris-Menifee had lowest RMSE with the station that was furthest away (Pomona).

In Central and Northern California, there was a similar lack of clear relationships between CIMIS station distance and $\mathrm{ET}_{0}$ accuracy (Tables 7, 8). As expected, RMSE was lower for both Monterey Bay and Sonoma Valleys due to the lower mean $\mathrm{ET}_{0}$ in general compared to Inland Southern California. Across the larger Monterey Bay region, RMSE ranged from less than $0.1-0.64 \mathrm{~mm} \mathrm{day}^{-1}$, with the lowest RMSE coming from two stations (Carmel and Laguna Seca) that were a proximate pair (Table 7). Two stations' wind inputs, Watsonville West II and Carmel, resulted in the lowest error for three other stations each. For Sonoma Valley, there was less variation in error with wind inputs with one station (Windsor) resulting in the lowest error for all of the other stations (Table 8).

When we compared the differences between the monthly totals of FAO-56 and Priestley-Taylor (PT) ET $_{0}$ at the CIMIS stations, a few general patterns emerge. Inland Southern California had the largest differences between FAO-56 and PT, with four of the five stations having annual differences of over $500 \mathrm{~mm}$ (Table 9). The station with the 
Table 5 Comparison of the different $\mathrm{ET}_{0}$ products for estimating $K_{\mathrm{c}}$ and plant water use, comparing the mean $\mathrm{ET}_{\mathrm{c}}$, root-mean-squared error (RMSE), and coefficient of variation $(\mathrm{CV})$

\begin{tabular}{|c|c|c|c|c|c|c|}
\hline \multirow[t]{2}{*}{ Reference ET product } & \multicolumn{3}{|l|}{ Grape } & \multicolumn{3}{|c|}{ Jerusalem Artichoke } \\
\hline & $\begin{array}{l}\text { Mean } \mathrm{ET}_{\mathrm{c}} \\
\left(\mathrm{mm} \mathrm{period}^{-1}\right)\end{array}$ & RMSE & $\mathrm{CV}$ & $\begin{array}{l}\text { Mean } \mathrm{ET}_{\mathrm{c}} \\
\left(\mathrm{mm} \mathrm{period}^{-1}\right)\end{array}$ & RMSE & $\mathrm{CV}$ \\
\hline USSL WS ET ${ }_{0}$ & 3.53 & 0.63 & 0.42 & 104.2 & 22.1 & 0.35 \\
\hline UCR CIMIS ET ${ }_{0}$ & 4.06 & 0.99 & 0.46 & 110.7 & 40.2 & 0.42 \\
\hline UCR merged $\mathrm{ET}_{0}$ & 3.4 & 0.62 & 0.40 & 92.4 & 30.5 & 0.44 \\
\hline Spatial CIMIS ET 0 & 4.23 & 1.16 & 0.45 & 124.8 & 37.1 & 0.34 \\
\hline USSL WS Hargreaves-Samani $\mathrm{ET}_{0}$ & 4.37 & 1.34 & 0.46 & 125.6 & 38.0 & 0.33 \\
\hline USSL WS Priestley-Taylor $\mathrm{ET}_{0}$ & 3.56 & 0.65 & 0.40 & 106.6 & 23.5 & 0.34 \\
\hline Moreno CIMIS ET 0 & 3.95 & 0.87 & 0.45 & 108.9 & 38.5 & 0.41 \\
\hline Perris CIMIS ET 0 & 4.37 & 1.26 & 0.45 & 119.4 & 45.5 & 0.4 \\
\hline Winchester CIMIS $\mathrm{ET}_{0}$ & 4.01 & 0.93 & 0.43 & 113.8 & 42.3 & 0.42 \\
\hline Pomona CIMIS ET ${ }_{0}$ & 3.95 & 0.87 & 0.45 & 92.4 & 31.6 & 0.42 \\
\hline
\end{tabular}

For comparison purposes, mean measured ET from the grape lysimeter was $3.41 \mathrm{~mm}$ period ${ }^{-1}$. Mean measured ET from the Jerusalem artichoke lysimeter was $92.8 \mathrm{~mm}_{\text {period }}{ }^{-1}$

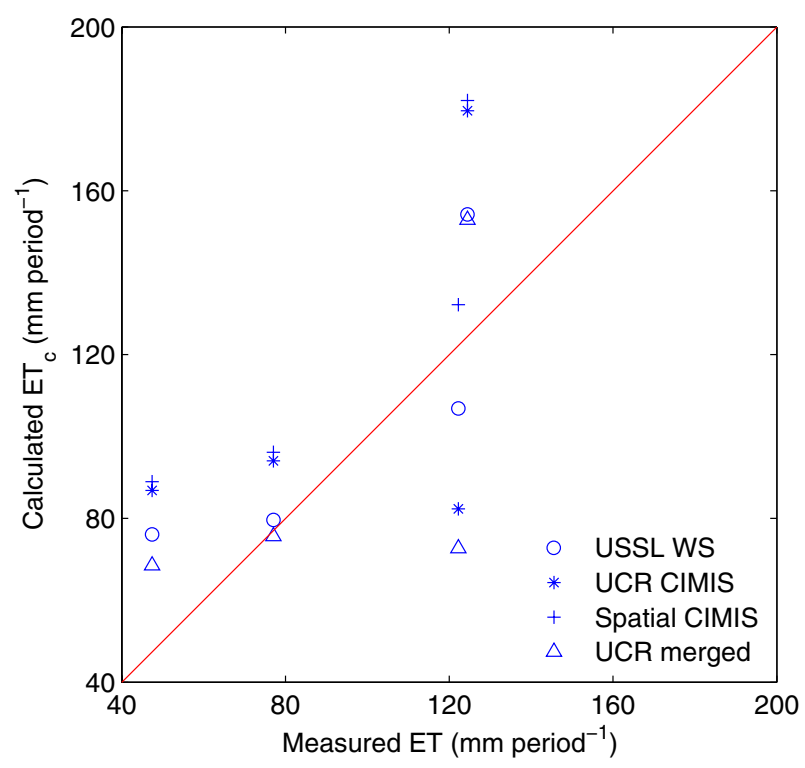

Fig. 6 Measured versus calculated evapotranspiration (ET) for the Jerusalem artichoke lysimeters. Calculated ET $\left(\mathrm{ET}_{\mathrm{c}}\right)$ was determined using the different $\mathrm{ET}_{0}$ products multiplied by mid-period crop coefficient adjusted for the effects of the elevated lysimeters (Skaggs et al. 2006). Line on graph is 1:1 line

greatest coastal influence (Pomona) also had the lowest differences. The largest monthly differences came in winter (January and February) and late fall (October-November), with the lowest differences for most sites in early summer. Monthly and annual differences between FAO-56 and PT $\mathrm{ET}_{0}$ were much lower in the Northern California regions (Tables 10,11). The Monterey Bay stations had PT $\mathrm{ET}_{0}$ that largely exceeded the FAO-56 $\mathrm{ET}_{0}$ (Table 10), while the Sonoma Valley had low positive differences between FAO56 and $\mathrm{PT} \mathrm{ET}_{0}$ (Table 11). For both regions, the largest positive deviations between FAO-56 and PT ET 0 occurred in fall,
Table 6 Comparison of $\mathrm{ET}_{0}$ accuracy using different wind inputs for CIMIS stations in inland Southern California including UCR (UCR), Moreno Valley (MV), Perris-Menifee (PM), Winchester (WI), and Pomona (PO)

\begin{tabular}{llllll}
\hline & UCR & MV & PM & WI & PO \\
\hline UCR & & 0.65 & $\mathbf{0 . 4 1}$ & 0.87 & 0.87 \\
MV & $\mathbf{0 . 6 3}$ & & 0.67 & 0.98 & 0.79 \\
PM & 0.41 & 0.66 & & 0.98 & $\mathbf{0 . 3 8}$ \\
WI & 0.73 & 0.91 & 0.77 & & $\mathbf{0 . 3 8}$ \\
PO & 0.43 & 0.66 & $\mathbf{0 . 3 3}$ & $\mathbf{0 . 3 3}$ & \\
\hline
\end{tabular}

Left-hand column indicates reference ET station using all data except wind speed. Top row indicates CIMIS station wind speed that is then inputted to complete $\mathrm{ET}_{0}$ equation. Cell values are root-mean-squared error (RMSE- units of $\mathrm{mm} \mathrm{day}^{-1}$ ) of original station $\mathrm{ET}_{0}$ minus station $\mathrm{ET}_{0}$ recalculated with new wind input. Bolded number indicates alternate wind speed location that has lowest RMSE for each CIMIS station

while the largest negative deviations occurred in early summer. Deviations within each region did not appear related to station distance between each other.

\section{Discussion}

\section{Impact of reference meteorological station and equation on water use parameterization}

In our study, the choice of meteorological station and equation had a major impact on the $\mathrm{ET}_{0}$ used to parameterize crop use. Of the equations that did not directly compensate for aerodynamic transport, Hargreaves-Samani had the poorest performance, while Priestley-Taylor with $\alpha=1.26$ performed reasonably well for predicting $\mathrm{ET}_{\mathrm{c}}$ at USSL, where wind was reduced, but had poor inter-comparisons against 
Table 7 Comparison of $\mathrm{ET}_{0}$ accuracy using different wind inputs for CIMIS stations in the Monterey Bay region, Central California, including Castroville (C), De Laveaga (DL), Green Valley Road (GV), Salinas North (SN), Pajaro (PA), Pacific Grove (PG), Watsonville West II (WW), Carmel (C2), and Laguna Seca (LS)
Table 8 Comparison of $\mathrm{ET}_{0}$ accuracy using different wind inputs for CIMIS stations in the Sonoma Valley region, Northern California, including Santa Rosa (SR), Windsor (WI), Petaluma East (PE), and Bennett Valley (BV)

\begin{tabular}{llllllllll}
\hline & C & DL & GV & SN & PA & PG & WW & C2 & LS \\
\hline C & & 0.15 & 0.20 & 0.38 & 0.28 & 0.23 & 0.24 & 0.15 & $\mathbf{0 . 1 4}$ \\
DL & 0.34 & & 0.18 & 0.59 & 0.35 & 0.46 & 0.35 & $\mathbf{0 . 1 3}$ & 0.15 \\
GV & 0.37 & 0.18 & & 0.64 & 0.37 & 0.45 & 0.41 & $\mathbf{0 . 1 6}$ & 0.18 \\
SN & 0.49 & 0.48 & 0.55 & & 0.29 & 0.30 & $\mathbf{0 . 2 4}$ & 0.48 & 0.49 \\
PA & 0.39 & 0.33 & 0.37 & 0.34 & & 0.27 & $\mathbf{0 . 1 4}$ & 0.31 & 0.32 \\
PG & 0.24 & 0.27 & 0.28 & 0.24 & 0.19 & & $\mathbf{0 . 1 5}$ & 0.26 & 0.26 \\
WW & 0.27 & 0.25 & 0.32 & 0.22 & $\mathbf{0 . 1 2}$ & 0.20 & & 0.26 & 0.27 \\
C2 & 0.23 & 0.10 & 0.15 & 0.52 & 0.31 & 0.32 & 0.31 & & $\mathbf{0 . 0 7}$ \\
LS & 0.23 & 0.12 & 0.15 & 0.54 & 0.34 & 0.36 & 0.33 & $\mathbf{0 . 0 8}$ & \\
\hline
\end{tabular}

As with Table 6, left-hand column indicates reference ET station using all data except wind speed. Top row indicates CIMIS station wind speed that is then inputted to complete $\mathrm{ET}_{0}$ equation. Cell values are rootmean-squared error (RMSE - units of $\mathrm{mm} \mathrm{day}^{-1}$ ) of original station $\mathrm{ET}_{0}$ minus station $\mathrm{ET}_{0}$ recalculated with new wind input. Bolded number indicates alternate wind speed location that has lowest RMSE for each CIMIS station. RMSE is lower overall than inland Southern California as average ET $_{0}$ is considerably lower due to Monterey's coastal proximity

\begin{tabular}{lllll}
\hline & SR & WI & PE & BV \\
\hline SR & & $\mathbf{0 . 2 3}$ & $\mathbf{0 . 2 3}$ & 0.39 \\
WI & 0.27 & & $\mathbf{0 . 2 1}$ & 0.29 \\
PE & 0.19 & $\mathbf{0 . 1 4}$ & & 0.19 \\
BV & 0.43 & $\mathbf{0 . 2 8}$ & 0.29 & \\
\hline
\end{tabular}

Inter-comparisons show RMSE and are identical to those shown in Tables 6 and 7 other $\mathrm{ET}_{0}$ stations and equations, particularly windier sites. This is consistent with the previous studies, finding that PT was lower than FAO-56 $\mathrm{ET}_{0}$ at drier and windier sites (Cristea et al. 2013; Liu et al. 2017; Tongwane et al. 2017). Somewhat contrary to general expectations, the CIMIS PM $\mathrm{ET}_{0}$ performance for the grape lysimeter did not decrease monotonically with increased distance, with Perris-Menifee and Pomona having lower CV and RMSE than the next closer station (Moreno Valley and Winchester, respectively). The patterns and response of the Jerusalem artichoke were
Table 9 Sum of differences between FAO-56 and PriestleyTaylor $\mathrm{ET}_{0}$ for CIMIS stations in inland Southern California including UCR (UCR), Moreno Valley (MV), Perris-Menifee $(\mathrm{PM})$, Winchester (WI), and Pomona (PO)
Table 10 Sum of differences between FAO-56 and PriestleyTaylor $\mathrm{ET}_{0}$ for CIMIS stations in Monterey Bay, California, including Castroville (C), De Laveaga (DL), Green Valley Road (GV), Salinas North (SN), Pajaro (PA), Pacific Grove (PG), Watsonville West II (WW), Carmel (C2), and Laguna Seca (LS)

\begin{tabular}{lrccrrrrrrrrrr}
\hline & Jan & Feb & Mar & Apr & May & Jun & Jul & Aug & Sep & Oct & Nov & Dec & Ann \\
\hline UCR & 114 & 62 & 75 & 63 & 39 & 16 & 17 & 27 & 34 & 38 & 49 & 31 & 566 \\
MV & 133 & 62 & 69 & 57 & 46 & 22 & 27 & 25 & 38 & 36 & 60 & 26 & 599 \\
PER & 97 & 62 & 70 & 69 & 58 & 42 & 45 & 41 & 49 & 48 & 54 & 21 & 657 \\
POM & 49 & 23 & 14 & 0 & -12 & -20 & -10 & -7 & 4 & 12 & 21 & 10 & 83 \\
WIN & 86 & 63 & 71 & 68 & 40 & 41 & 24 & 21 & 34 & 49 & 46 & 17 & 561 \\
\hline
\end{tabular}

Monthly differences are in units of mm month ${ }^{-1}$. Annual (Ann) totals are in mm year ${ }^{-1}$ for the 2014-2015 period. Positive numbers indicate FAO-56 exceeding Priestley-Taylor

\begin{tabular}{lrrrrrrrrrrrrr}
\hline & Jan & Feb & Mar & Apr & May & Jun & Jul & Aug & Sep & Oct & Nov & Dec & Ann \\
\hline C & 15 & 6 & -8 & -17 & -25 & -22 & -26 & -21 & -14 & 13 & 7 & 4 & -88 \\
DL & 23 & 11 & 8 & -1 & -17 & -20 & -20 & -16 & -5 & 16 & 15 & 7 & 0 \\
GV & 20 & 16 & 6 & -2 & -13 & -19 & -19 & -15 & -4 & 16 & 11 & 9 & 7 \\
SN & 41 & 29 & 20 & 9 & -12 & -22 & -25 & -14 & -8 & 27 & 26 & 16 & 89 \\
PA & 39 & 16 & 6 & 2 & -17 & -10 & -8 & -4 & 4 & 25 & 27 & 24 & 104 \\
PG & 18 & 10 & -11 & -21 & -31 & -41 & -37 & -25 & -19 & 12 & 10 & 15 & -123 \\
WW & 27 & 13 & 5 & -3 & -22 & -28 & -25 & -21 & -12 & 20 & 18 & 14 & -13 \\
C2 & 25 & 15 & 4 & -8 & -19 & -29 & -29 & -20 & -11 & 16 & 18 & 12 & -25 \\
LS & 22 & 15 & 5 & -3 & -11 & -18 & -20 & -14 & -4 & 16 & 18 & 10 & 15 \\
\hline
\end{tabular}

Monthly differences are in units of mm month ${ }^{-1}$. Annual (Ann) totals are in mm year ${ }^{-1}$ for the 2014-2015 period. Positive numbers indicate FAO-56 exceeding Priestley-Taylor 
Table 11 Sum of differences between FAO-56 and Priestley-Taylor ET ${ }_{0}$ for CIMIS stations in the Sonoma Valley region, Northern California, including Santa Rosa (SR), Windsor (WI), Petaluma East (PE), and Bennett Valley (BV)

\begin{tabular}{llllllrrrrrrrrr}
\hline & Jan & Feb & Mar & Apr & May & Jun & Jul & Aug & Sep & Oct & Nov & Dec & Ann \\
\hline SR & 8 & 11 & 2 & 2 & -15 & 1 & 4 & 7 & 19 & 40 & 20 & 10 & 109 \\
WI & 8 & 10 & 8 & 8 & -11 & 9 & 4 & 8 & 13 & 28 & 13 & 6 & 102 \\
PE & 6 & 7 & 0 & -4 & -18 & -13 & -4 & -3 & 6 & 20 & 13 & 7 \\
BV & 6 & 0 & 2 & -3 & -20 & -12 & -11 & -6 & 3 & 24 & 15 & 5 & 3 \\
\hline
\end{tabular}

Monthly differences are in units of $\mathrm{mm}$ month $^{-1}$. Annual (Ann) totals are in mm year ${ }^{-1}$ for the 2014-2015 period. Positive numbers indicate FAO-56 exceeding Priestley-Taylor

different, with only one product, Spatial CIMIS, having approximately the same level of performance for both the crops. The lack of a consistent change in $\mathrm{ET}_{0}$ performance with increasing distance (Table 5) and inconsistent response of $\mathrm{ET}_{0}$ error to distance of wind input (Tables 6, 7, 8) also argue against the common practice in California of using the next closest CIMIS station when the closest one has instrumentation failures or lack of maintenance on the reference grass surface. Instead, an interpolated approach which relies on multiple stations, such as the Spatial CIMIS interpolation approaches (Hart et al. 2009), may be more appropriate. Given that most meteorology in Southern California is driven by large-scale interactions between the Pacific Ocean and Mojave and Sonoran deserts, implementation of higher resolution wind speed predictions using Large Eddy Simulations (Mirocha et al. 2012) may help to improve $\mathrm{ET}_{0}$ prediction in Southern California, particularly in sheltered areas such as the USSL research site that have reduced winds or exposed areas such as ridges or passes with higher winds. For homeowners and landscape managers, the uncertainty in $\mathrm{ET}_{0}$ argues for closer examination of the $\mathrm{ET}_{0}$ used for estimating consumptive use as well as a cross-validation against soil water content as predicted by water budget approaches (e.g. Andales et al. 2014). Although validation against water budgets has its own challenges, it can be relatively simpler for more homogeneous, sprinkler-irrigated landscapes such as grasslands and closely spaced row crops.

\section{Integration of meteorological products from different sources to improve irrigation}

There can be difficulty transferring $K_{\mathrm{c}}$ among regions, resulting in a need for climatic adjustments to $K_{\mathrm{c}}$ (Allen et al. 1998; Guerra et al. 2015). However, if the $\mathrm{ET}_{0}$ used in irrigation scheduling does not reflect the local site meteorology or unique microclimate (Anderson et al. 2015), the computed crop ET can be erroneous, resulting in over-irrigation and waste of potentially expensive water and energy or underirrigation and crop water stress on a high-value crop or landscape with other expensive inputs. Having an $\mathrm{ET}_{0}$ that is truly reflective of local micrometeorology should result in an improved $\mathrm{ET}_{\mathrm{c}}$ with a $K_{\mathrm{c}}$ that better reflects agronomic and plant physiological conditions (plant cover, soil moisture/salinity status, agronomic management, etc.). A more representative $\mathrm{ET}_{0}$ that improves calculation of $\mathrm{ET}_{\mathrm{c}}$ should also help to improve the stability of soil moisture outputs for water budget-based approaches that are developed for irrigator use (Wright 2002; Rogers and Alam 2006; Andales et al. 2014; Bartlett et al. 2015). These outputs are used to help schedule optimal irrigations, but, in recognizing the uncertainty of ET calculations, most program developers recommend validation of water balance model soil moisture against field observations at multiple times during the cropping season. This validation can be complicated, especially in drip or micro-irrigated fields with complex and timevariant, two- and three-dimensional wetting patterns (Cote et al. 2003; Skaggs et al. 2004). This results in validation efforts that can be labor intensive or expensive to gather the appropriate amount of gravimetric samples or to install sufficient sensors to monitor moisture content.

For both lysimeters and crops in our study, incorporation of on-field wind speed has reduced the variability of calculated $\mathrm{ET}_{\mathrm{c}}$. The calculated $\mathrm{ET}_{\mathrm{c}}$ values in our grape field were in excellent agreement with measured lysimeter values despite the very low $K_{\mathrm{c}}$ values calculated from surface coverage (Fig. 5), while the Jerusalem artichoke had closer agreement on mean $\mathrm{ET}_{\mathrm{c}}$ with local wind despite variability at higher evaporative demand (Table 5; Fig. 6). In other semiarid regions of the United States, wind speed uncertainty has the greatest sensitivity impact on $\mathrm{ET}_{0}$ with typical sensor errors (DeJonge et al. 2015). However, most approaches to estimate field-scale $\mathrm{ET}_{0}$, primarily incorporating satellite remote sensing, either rely on geospatial interpolation of wind speed between stations (Hart et al. 2009) or using a simplified version of the Penman-Monteith approach that omits wind speed altogether (Westerhoff 2015).

The results of our study indicate that growers and irrigation managers in semi-arid regions with complex topography should consider on-field wind speed data to optimize $\mathrm{ET}_{0}$ estimates, even if there is a suitable $\mathrm{ET}_{0}$ station in relatively close proximity. The need to use on-field meteorology may be particularly indicated if (1) outputs of the existing 
irrigation scheduling programs (soil moisture, plant water status, etc.) quickly diverge from actual field conditions, (2) there is good reason to suspect that on-farm meteorology differs from the nearest weather station, and (3) the costs of additional and/or unscheduled irrigations are high. We recognize the cost and logistical effort necessary for such an approach, but the incorporation of local wind data results in improved $\mathrm{ET}_{\mathrm{c}}$, which may improve the prediction ability of irrigation scheduling based on forecasted water budget (Wright 2002; Andales et al. 2014). Over the course of a season, these differences in $\mathrm{ET}_{\mathrm{c}}$ can be quite substantial. For the Jerusalem artichoke, using the UCR CIMIS $\mathrm{ET}_{0}$ resulted in a calculated $\mathrm{ET}_{\mathrm{c}}$ that was $71 \mathrm{~mm}$ higher than measured ET over the 45 day measurement period, whereas using the UCR merged $\mathrm{ET}_{0}$ resulted in a cumulative difference of $1 \mathrm{~mm}$ for the entire period. Similarly, for the grape lysimeters with young vines, using UCR CIMIS ET $_{0}$ resulted in calculated $\mathrm{ET}_{\mathrm{c}}$ that was $26 \mathrm{~L}_{\text {vine }}{ }^{-1}$ higher than cumulative water use $\left(136 \mathrm{~L}\right.$ vine $\left.^{-1}\right)$, whereas the merged product had a cumulative difference of less than $1 \mathrm{~L}$ vine ${ }^{-1}$. Institutional emphasis on time of day irrigation scheduling to avoid peak electrical costs (Fleming 2014) further suggests the need for near real-time $\mathrm{ET}_{0}$ and $\mathrm{ET}$ calculation to forecast irrigation needs. Where suitable $\mathrm{ET}_{0}$ stations are more distant, farmers, or farmer cooperatives could install a full meteorological station to better parameterize $\mathrm{ET}_{0}$ or use satellite inputs (Hart et al. 2009; Westerhoff 2015) for variables, such as net radiation and land surface temperature, that can be reliably obtained from satellites. Where available, a well-watered, full canopy crop may be a suitable alternate reference surface to short grass or alfalfa (Irmak and Odhiambo 2009; Skaggs and Irmak 2012).

\section{Summary and conclusion}

In this study, we examined the impact of different $\mathrm{ET}_{0}$ products and data sources on crop $\mathrm{ET}_{\mathrm{c}}$ calculation using data from two different crops, wine grapes and Jerusalem artichoke, on two different lysimeter systems, weighing and volumetric. Our investigation showed the substantial difference in wind speed between the two closest meteorological stations despite their relatively close proximity (less than $3 \mathrm{~km}$ apart) and a large regional discrepancy in wind speeds. This microclimatological difference resulted in substantial differences in daily and annual sums of $\mathrm{ET}_{0}$, with the merged meteorological product having the lowest annual $\mathrm{ET}_{0}$. The products with local wind speed had better stability of $\mathrm{ET}_{\mathrm{c}}$, better agreement between measured $\mathrm{ET}$ and $\mathrm{ET}_{\mathrm{c}}$ and lower RMSE in both grape and Jerusalem artichoke, though the more stable product differed between the wine grape lysimeter (merged $\mathrm{ET}_{0}$ ) and the Jerusalem artichoke (local meteorological station). For the regional analysis, the variable RMSE with distance of wind input illustrates the high heterogeneity of wind in regions with complex topography and coastal interactions. The high variability in difference between FAO-56 and Priestley-Taylor ET ${ }_{0}$ between regions and among stations within the same region argues against using simplified $\mathrm{ET}_{0}$ equations that do not explicitly consider aerodynamic transport.

The clear impact of micro-climatology on $\mathrm{ET}_{0}$ illustrates the need for accurate, farm, and field-specific parameterization of $\mathrm{ET}_{0}$, with a particular emphasis on accurate wind speed observations in semi-arid and arid regions with complex topography. If even a relatively small portion $(>5-10 \%)$ of the considerable difference in annual $\mathrm{ET}_{0}$ in our study (range of $349 \mathrm{~mm} \mathrm{year}^{-1}$ from the lowest to highest $\mathrm{ET}_{0}$ products) can be translated into actual water savings for the grower, it will have a net significant financial benefit in regions with highly expensive and/or scarce water even after accounting for additional costs, maintenance, and incorporation on-field meteorological sensors. This difference and potential savings will likely continue to increase in the future with decreasing sensor and networking costs and increased expense for water and manual irrigation management.

Acknowledgements We would like to thank Martin Angulo, Jeffrey Geiger, Teresa Clapp, and Charmaine Mutuc for their assistance with the grape lysimeter observations and USSL weather station. Tessa Ries, William Yee, and Alan Malagon helped with the Jerusalem artichoke measurements. We thank and acknowledge the editor and anonymous reviewers for their constructive comments on an earlier version of this manuscript. The research grape field and lysimeters were funded in part by a grant from USDA-National Institute of Food and Agriculture. This research was also supported by USDA-ARS National Program 211: Water Availability and Water Management (Project nos. 2036-61000015-00, 2036-13210-010-00, and 2036-61000-016-00).

\section{References}

Allen RG, Pereira LS, Raes D, Smith M (1998) Crop evapotranspiration: guidelines for computing crop water requirements. Food and Agriculture Organization of the United Nations, Rome

Allen RG, Walter IA, Elliott RL et al (2005) The ASCE standardized reference evapotranspiration equation. American Society of Civil Engineers, Reston

Andales AA, Bauder TA, Arabi M (2014) A mobile irrigation water management system using a collaborative GIS and weather station networks. In: Practical applications of agricultural system models to optimize the use of limited water. American Society of Agronomy, Inc., Crop Science Society of America, Inc., and Soil Science Society of America, Inc., Madison, pp 53-84

Anderson RG, Wang D, Tirado-Corbalá R et al (2015) Divergence of actual and reference evapotranspiration observations for irrigated sugarcane with windy tropical conditions. Hydrol Earth Syst Sci 19:583-599. doi:10.5194/hess-19-583-2015

Ayars JE, Fulton A, Taylor B (2015) Subsurface drip irrigation in California-here to stay? Agric Water Manag 157:39-47. doi:10.1016/j.agwat.2015.01.001

Bartlett AC, Andales AA, Arabi M, Bauder TA (2015) A smartphone app to extend use of a cloud-based irrigation scheduling 
tool. Comput Electron Agric 111:127-130. doi:10.1016/j. compag.2014.12.021

Bitella G, Rossi R, Bochicchio R et al (2014) A novel low-cost openhardware platform for monitoring soil water content and multiple soil-air-vegetation parameters. Sensors 14:19639-19659. doi:10.3390/s141019639

Carrow RN (2006) Can we maintain turf to customers' satisfaction with less water? Agric Water Manag 80:117-131. doi:10.1016/j. agwat.2005.07.008

Chaves MM, Santos TP, Souza CR et al (2007) Deficit irrigation in grapevine improves water-use efficiency while controlling vigour and production quality. Ann Appl Biol 150:237-252. doi:10.1111/j.1744-7348.2006.00123.x

Chiang C-T (2015) Design of a CMOS digitized wind transducer with noise insensitivity for wind environmental monitoring applications. IEEE Sens J 15:2046-2053. doi:10.1109/ JSEN.2014.2365811

Christian-Smith J, Levy MC, Gleick PH (2014) Maladaptation to drought: a case report from California, USA. Sustain Sci. doi:10.1007/s11625-014-0269-1

Conil S, Hall A (2006) Local regimes of atmospheric variability: a case study of Southern California. J Clim 19:4308-4325. doi:10.1175/ JCLI3837.1

Connor JD, Schwabe K, King D, Knapp K (2012) Irrigated agriculture and climate change: the influence of water supply variability and salinity on adaptation. Ecol Econ 77:149-157. doi:10.1016/j. ecolecon.2012.02.021

Cornacchione MV, Suarez DL (2015) Emergence, forage production, and ion relations of Alfalfa in response to saline waters. Crop Sci 55:444-457. doi:10.2135/cropsci2014.01.0062

Cote CM, Bristow KL, Charlesworth PB et al (2003) Analysis of soil wetting and solute transport in subsurface trickle irrigation. Irrig Sci 22:143-156. doi:10.1007/s00271-003-0080-8

Courault D, Ruget F (2001) Impact of local climate variability on crop model estimates in the south-east of France. Clim Res 18:195204. doi:10.3354/cr018195

Cristea NC, Kampf SK, Burges SJ (2013) Revised coefficients for Priestley-Taylor and Makkink-Hansen equations for estimating daily reference evapotranspiration. J Hydrol Eng 18:1289-1300. doi:10.1061/(ASCE)HE.1943-5584.0000679

DeJonge KC, Ahmadi M, Ascough JC, Kinzli K-D (2015) Sensitivity analysis of reference evapotranspiration to sensor accuracy. Comput Electron Agric 110:176-186. doi:10.1016/j. compag.2014.11.013

Delfine S, Loreto F, Alvino A (2001) Drought-stress effects on physiology, growth and biomass production of rainfed and irrigated bell pepper plants in the mediterranean region. J Am Soc Hortic Sci 126:297-304

Dias NS, Ferreira JFS, Liu X, Suarez DL (2016) Jerusalem artichoke (Helianthus tuberosus, L.) maintains high inulin, tuber yield, and antioxidant capacity under moderately-saline irrigation waters. Ind Crops Prod 94:1009-1024. doi:10.1016/j.indcrop.2016.09.029

Dias NS, Ferreira JFS, Liu X, Suarez DL Jerusalem artichoke (Helianthus tuberosus, L.) maintains high inulin, tuber yield, and antioxidant capacity under moderately-saline irrigation waters. Ind Crops Prod. doi:10.1016/j.indcrop.2016.09.029

Diffenbaugh NS, Swain DL, Touma D (2015) Anthropogenic warming has increased drought risk in California. Proc Natl Acad Sci 112:3931-3936. doi:10.1073/pnas.1422385112

Doorenbos J, Pruitt W (1977) Crop water requirements. FAO irrigation and drainage paper 24

Eching S, Moellenberndt D, California. Department of Water Resources. Division of Planning and Local Assistance (1998) Technical elements of CIMIS, the California irrigation management information system. State of California, Resources Agency,
Department of Water Resources, Division of Planning and Local Assistance

Elliott J, Deryng D, Müller C et al (2014) Constraints and potentials of future irrigation water availability on agricultural production under climate change. Proc Natl Acad Sci 111:3239-3244. doi:10.1073/pnas.1222474110

Eskridge RE, Ku JY, Rao ST et al (1997) Separating different scales of motion in time series of meteorological variables. Bull Am Meteorol Soc 78:1473-1483. doi:10.1175/1520-0477(1997)078<1473:SDSOMI > 2.0.CO;2

Falkenmark M (2013) Growing water scarcity in agriculture: future challenge to global water security. Philos Trans R Soc Math Phys Eng Sci 371:20120410-20120410. doi:10.1098/rsta.2012.0410

Famiglietti JS (2014) The global groundwater crisis. Nat Clim Change 4:945-948. doi:10.1038/nclimate2425

Fleming P (2014) CA farmers find unlikely ally in weathering drought: a major utility company. In: Water Curr. Blog - Natl. Geogr. http://voices.nationalgeographic.com/2014/08/12/ca-farmers-findunlikely-ally-in-weathering-drought-a-major-utility-company/. Accessed 24 Aug 2015

Gleick PH (2002) Water management: Soft water paths. Nature 418:373-373. doi:10.1038/418373a

Guerra E, Ventura F, Spano D, Snyder RL (2015) Correcting midseason crop coefficients for climate. J Irrig Drain Eng 141:04014071. doi:10.1061/(ASCE)IR.1943-4774.0000839

Han D, Kim S, Park S (2008) Two-dimensional ultrasonic anemometer using the directivity angle of an ultrasonic sensor. Microelectron J 39:1195-1199. doi:10.1016/j.mejo.2008.01.090

Hargreaves GH, Samani ZA (1985) Reference crop evapotranspiration from temperature. Appl Eng Agric 1:96-99. doi: $10.13031 / 2013.26773$

Hart QJ, Brugnach M, Temesgen B et al (2009) Daily reference evapotranspiration for California using satellite imagery and weather station measurement interpolation. Civ Eng Environ Syst 26:19-33

Hoekstra AY, Mekonnen MM, Chapagain AK et al (2012) Global monthly water scarcity: blue water footprints versus blue water availability. PLoS One 7:e32688. doi:10.1371/journal. pone. 0032688

Howitt RE (2014) Are lease water markets still emerging in California? In: Easter KW, Huang Q (eds) Water markets for the 21st century. Springer Netherlands, Dordrecht, pp 83-102

Irmak S, Odhiambo LO o (2009) Impact of microclimatic data measured above maize and grass canopies on Penman-Monteith reference evapotranspiration calculations. Trans ASABE 52:11551169. doi:10.13031/2013.27796

Jensen ME, Robb DCN, Franzoy CE (1970) Scheduling irrigations using climate-crop-soil data. Proc Am Soc Civ Eng J Irrig Drain Div 96:25-38

Lamm FR, Abou Kheira AA, Trooien TP (2010) Sunflower, soybean, and grain sorghum crop production as affected by dripline depth. Appl Eng Agric 26:873-882. doi:10.13031/2013.34952

Litvak E, Pataki DE (2016) Evapotranspiration of urban lawns in a semi-arid environment: an in situ evaluation of microclimatic conditions and watering recommendations. J Arid Environ 134:8796. doi: 10.1016/j.jaridenv.2016.06.016

Liu X, Xu C, Zhong X et al (2017) Comparison of 16 models for reference crop evapotranspiration against weighing lysimeter measurement. Agric Water Manag 184:145-155. doi:10.1016/j. agwat.2017.01.017

Lopez G, Hossein Behboudian M, Girona J, Marsal J (2012) Drought in deciduous fruit trees: implications for yield and fruit quality. In: Aroca R (ed) Plant responses to drought stress. Springer, Berlin Heidelberg, pp 441-459

Makkink G (1957) Testing the Penman formula by means of lysimeters. J Inst Water Eng 11:277-288 
McMahon TA, Peel MC, Lowe L et al (2013) Estimating actual, potential, reference crop and pan evaporation using standard meteorological data: a pragmatic synthesis. Hydrol Earth Syst Sci 17:1331-1363. doi:10.5194/hess-17-1331-2013

McVicar TR, Roderick ML, Donohue RJ et al (2012) Global review and synthesis of trends in observed terrestrial near-surface wind speeds: Implications for evaporation. J Hydrol 416-417:182-205. doi:10.1016/j.jhydrol.2011.10.024

Mirocha J, Kirkil G, Bou-Zeid E et al (2012) Transition and equilibration of neutral atmospheric boundary layer flow in one-way nested large-Eddy simulations using the weather research and forecasting model. Mon Weather Rev 141:918-940. doi:10.1175/ MWR-D-11-00263.1

Monti A, Amaducci MT, Venturi G (2005) Growth response, leaf gas exchange and fructans accumulation of Jerusalem artichoke (Helianthus tuberosus L.) as affected by different water regimes. Eur J Agron 23:136-145. doi:10.1016/j.eja.2004.11.001

Nouri H, Beecham S, Hassanli AM, Kazemi F (2013a) Water requirements of urban landscape plants: a comparison of three factorbased approaches. Ecol Eng 57:276-284. doi:10.1016/j.ecoleng.2013.04.025 a)

Nouri H, Beecham S, Kazemi F, Hassanli AM (2013b) A review of ET measurement techniques for estimating the water requirements of urban landscape vegetation. Urban Water J 10:247-259. doi:10.1 080/1573062X.2012.726360 b)

Ors S, Suarez DL (2016) Salt tolerance of spinach as related to seasonal climate. Hortic Sci 43:33-41. doi:10.17221/114/2015-HORTSCI

Petts GE (2009) Instream flow science for sustainable river management. JAWRA J Am Water Resour Assoc 45:1071-1086. doi:10.1111/j.1752-1688.2009.00360.x

Pierce FJ, Elliott TV (2008) Regional and on-farm wireless sensor networks for agricultural systems in Eastern Washington. Comput Electron Agric 61:32-43. doi:10.1016/j.compag.2007.05.007

Poss JA, Russell WB, Bonos SA, Grieve CM (2010) Salt tolerance and canopy reflectance of kentucky bluegrass cultivars. HortScience 45:952-960

Postel SL (2000) Entering an era of water scarcity: the challenges ahead. Ecol Appl 10:941-948. doi:10.1890/1051-0761(2000)010[0941:EAEOWS]2.0.CO;2

Priestley CHB, Taylor RJ (1972) On the assessment of surface heat flux and evaporation using large-scale parameters. Mon Weather Rev 100:81-92. doi:10.1175/1520-0493(1972)100<0081:OTAO $\mathrm{SH}>2.3 . \mathrm{CO} ; 2$

Pritchett J, Thorvaldson J, Frasier M (2008) Water as a crop: limited irrigation and water leasing in Colorado. Rev Agric Econ 30:435444. doi:10.1111/j.1467-9353.2008.00417.x

Rogers DH, Alam M (2006) KanSched2. Kansas State University Research \& Extension Mobile Irrigation Lab, Manhattan

Rost S, Gerten D, Bondeau A et al (2008) Agricultural green and blue water consumption and its influence on the global water system. Water Resour Res. doi:10.1029/2007WR006331

Ruel J-C, Pin D, Cooper K (1998) Effect of topography on wind behaviour in a complex terrain. Forestry 71:261-265. doi:10.1093/ forestry/71.3.261

Ruttanaprasert R, Jogloy S, Vorasoot N et al (2016) Effects of water stress on total biomass, tuber yield, harvest index and water use efficiency in Jerusalem artichoke. Agric Water Manag 166:130 138. doi:10.1016/j.agwat.2015.12.022
Salvador R, Bautista-Capetillo C, Playán E (2011) Irrigation performance in private urban landscapes: a study case in Zaragoza (Spain). Landsc Urban Plan 100:302-311. doi:10.1016/j. landurbplan.2010.12.018

Scanlon BR, Faunt CC, Longuevergne L et al (2012) Groundwater depletion and sustainability of irrigation in the US High Plains and Central Valley. Proc Natl Acad Sci 109:9320-9325. doi: 10.1073/pnas.1200311109

Skaggs KE, Irmak S (2012) Analysis of microclimate data measured over grass and soybean canopy and their impacts on Penman-Monteith Grass and Alfalfa reference evapotranspiration. J Irrig Drain Eng 138:120-134. doi:10.1061/(ASCE) IR.1943-4774.0000382

Skaggs TH, Trout TJ, Šimůnek J, Shouse PJ (2004) Comparison of HYDRUS-2D simulations of drip irrigation with experimental observations. J Irrig Drain Eng 130:304-310. doi:10.1061/ (ASCE)0733-9437(2004)130:4(304)

Skaggs TH, Poss JA, Shouse PJ, Grieve CM (2006) Irrigating forage crops with saline waters. Vadose Zone J 5:815. doi:10.2136/ vzj2005.0119

Snyder RL, Pedras C, Montazar A et al (2015) Advances in ET-based landscape irrigation management. Agric Water Manag 147:187197. doi:10.1016/j.agwat.2014.07.024

Spano D, Snyder RL, Sirca C, Duce P (2009) ECOWAT-a model for ecosystem evapotranspiration estimation. Agric For Meteorol 149:1584-1596. doi:10.1016/j.agrformet.2009.04.011

Temesgen B, Allen RG, Jensen DT (1999) Adjusting temperature parameters to reflect well-watered conditions. J Irrig Drain Eng 125:26-33. doi:10.1061/(ASCE)0733-9437(1999)125:1(26)

Tongwane MI, Savage MJ, Tsubo M, Moeletsi ME (2017) Seasonal variation of reference evapotranspiration and Priestley-Taylor coefficient in the eastern Free State, South Africa. Agric Water Manag 187:122-130. doi:10.1016/j.agwat.2017.03.013

Valiantzas JD (2013) Simplified forms for the standardized FAO56 Penman-Monteith reference evapotranspiration using limited weather data. J Hydrol 505:13-23. doi:10.1016/j. jhydrol.2013.09.005

Vörösmarty CJ, Green P, Salisbury J, Lammers RB (2000) Global water resources: vulnerability from climate change and population growth. Science 289:284-288

Wang D (2002) Dynamics of soil water and temperature in aboveground sand cultures used for screening plant salt tolerance. Soil Sci Soc Am J 66:1484. doi:10.2136/sssaj2002.1484

Ward FA, Becker N (2015) Economic cost of water deliveries for peace and the environment in Israel: an integrated water resources management approach. Water Resour Res 5806-5826. doi:10.1002/2 014WR016783

Westerhoff RS (2015) Using uncertainty of Penman and PenmanMonteith methods in combined satellite and ground-based evapotranspiration estimates. Remote Sens Environ 169:102-112. doi:10.1016/j.rse.2015.07.021

Williams LE, Ayars JE (2005) Grapevine water use and the crop coefficient are linear functions of the shaded area measured beneath the canopy. Agr Forest Meteorol 132:201-211. doi:10.1016/j. agrformet.2005.07.010

Wright JL (2002) Irrigation scheduling checkbook method. University of Minnesota Extension, St. Paul 